Endocrinol. Japon. 1988, 35 (1), 143-148

\title{
A Reversed-Phase High-Performance Liquid Chromatographic Method for the Simultaneous Determination of Serum Concentrations of Cyproterone Acetate and $15 \beta$-Hydroxycyproterone Acetate
}

\author{
Kyotaro YODO, Sumitaka SAISHO, Kazuhiko SHIMOZAWA \\ AND JUN-ICHI YATA \\ Department of Pediatrics, Faculty of Medicine, Tokyo Medical \\ and Dental University, Tokyo 113, Japan
}

\begin{abstract}
A reversed-phase high-performance liquid chromatographic method for the simultaneous determination of cyproterone acetate (CPA), 15 $\beta$-hydroxycyproterone acetate $(15 \beta-\mathrm{OH}-\mathrm{CPA})$ and cyproterone $(\mathrm{CP})$ was reported. This method was specific, sensitive, precise, easy and rapid for determination of the serum concentrations of these steroids in patients receiving CPA. Although no peak corresponding to $\mathrm{CP}$ was observed for serum, peaks corresponding to CPA and $15 \beta-\mathrm{OH}-\mathrm{CPA}$ were detected and well separated in all subjects undergoing long-term CPA therapy. In these patients, there seemed to be a dose-dependent relationship between the amount of CPA administered and the serum concentrations of these steroids, and the serum concentrations of CPA were either similar or low compared with those of $15 \beta-\mathrm{OH}-\mathrm{CPA}$.

In conclusion, this simplified method is thought to be very valuable for studies on the pharmacokinetics of CPA and 15 $\beta-\mathrm{OH}-\mathrm{CPA}$, and on the relationship between the CPA dosage and the therapeutic or side effects on adrenal and gonadal steroid production.
\end{abstract}

Cyproterone acetate (17-acetoxy-6-chloro- $1 \alpha, 2 \alpha$-methylene-4, 6-pregnadiene-3, 20dione: $\mathrm{CPA}$ ) is one of the agents which are generally used for the treatment of sexual deviations, especially of true precocious puberty in childhood. Although several papers dealing with methods for the determination of CPA, involving radioimmunoassaying ( $\mathrm{R}$ IA) (Hümpel et al., 1978; Nieuweboer and

\section{Received September 16, 1987}

Address reprint requests to Dr. KYOTARO YODO at the Department of Pediatrics, Faculty of Medicine, Tokyo Medical and Dental University, 1-5-45 Yushima, Bunkyo-ku, Tokyo 113, Japan.
Lübke, 1977) or high-performance liquid chromatography (HPLC) (Cannell et al., 1981; Frith and Phillipou, 1985), have appeared the pharmacokinetics of CPA and its metabolites in patients undergoing longterm CPA therapy have not been sufficiently examined. In addition to this, not only an appropriate dosage and CPA therapy schedule but also the relationship between the dosage of CPA and the side effects on adrenal intrinsic steroid production has not yet been determined. In this paper, therefore, as one means of resolving these points, we report a modified reversed-phase HPLC 
method for the simultaneous determination of serum CPA, cyproterone (CP) and $15 \beta$ hydroxycyproterone acetate (15 $\beta$-OH-CPA), which is known to be the main and potential metabolite of CPA in serum (Schleusener et al., 1980).

\section{Subjects and Methods}

\section{Subjects}

Twenty-three serum samples for 11 patients with true precocious puberty and one patient with idiopathic hirsutism were examined. Two of them were patients with congenital adrenal hyperplasia due to 21-hydroxylase deficiency who developed true precocious puberty after the initiation of hydrocortisone therapy. The doses of CPA orally administered ranged from 41.6 to $208 \mathrm{mg} / \mathrm{m}^{2} /$ day. Most of the samples were obtained two hours after the oral administration of CPA.

\section{Methods}

The methanol and acetonitrile used for the mobile phase and the diethyl ether for sample extraction were all of HPLC-grade. Cyproterone (CP), cyproterone acetate (CPA) and 15 $\beta$-hydroxycyproterone aectate (15 $\beta$-OH-CPA) were kindly donated by Schering AG (Berlin, West Germany), and 19-nortestosterone (19-NT) and other steroids were all obtained from Sigma Chemical Co. (St. Louis, MO, USA).

The HPLC pump and UV spectrometer used were a TWINCLE and a UVIDEC $100-\mathrm{V}$ obtained from JASCO (Tokyo, Japan). The UV spectrometer was operated at a wavelength of $284 \mathrm{~nm}$, since CP, CPA and 15 $\beta-\mathrm{OH}-\mathrm{CPA}$ showed maximum absorbance at around this wavelength under our assay conditions, though the maximum absorbance of the internal standard, 19-NT was at around $246 \mathrm{~nm}$. We used ERC-ODS-1161 $(\phi 6 \mathrm{~mm} \times 20 \mathrm{~cm}$; particle size, $3 \mu)$ and ERCODS-1652 $(\phi 6 \mathrm{~mm} \times 3 \mathrm{~cm} ;$ particle size, $5 \mu)$ (both from ERMA, Tokyo, Japan) for the main column and the pre-column, respectively. A mixed solvent containing methanol, acetonitrile and water, 55/6/39 by volume, was used as the mobile phase, which was pumped at a constant flow rate of $1.8 \mathrm{ml} / \mathrm{min}$. The HPLC was conducted at room temperature.

One half milliliter of serum and $50 \mu \mathrm{l}(5 \mu \mathrm{g})$ of the internal standard, 19-NT, was extracted with $5.0 \mathrm{ml}$ of diethyl ether by vortex mixing in a test tube. The organic phase was washed with $0.5 \mathrm{ml}$ of distilled water and then separated by centrifugation at $3,000 \mathrm{rpm}$ for $2 \mathrm{~min}$. After evaporation of the solvent, the residue was dissolved in $50 \mu \mathrm{l}$ of methanol and then $20 \mu \mathrm{l}$ of the resultant solution was injected into the HPLC system.

We examined the retention time and recovery rate for each steroid, and the ratio of peak height for each steroid to that of the internal standard, 19-NT. Each steroid was identified on the basis of its retention time relative to that of 19-NT. We used the peak height ratio as the basis for quantitation.

The estimated values were expressed as mean \pm SD. Statistical analyses were performed with Student's unpaired $t$-test, and differences with $\mathbf{P}$ values of less than 0.05 were considered to be statistically significant.

\section{Results}

Tables 1 and 2 show the retention time and recovery rate for each steroid. Fig. 1

Table 1. Retention times and retention time ratios to the internal standard (19-nortestosterone).

\begin{tabular}{l|c:c|c:c}
\hline \hline & $\begin{array}{c}\text { Retention } \\
\text { time } \\
(\mathrm{min})\end{array}$ & $\begin{array}{c}\mathrm{CV} \\
(\%)\end{array}$ & $\begin{array}{c}\text { Retention } \\
\text { time } \\
\text { ratio }\end{array}$ & $\begin{array}{c}\mathrm{CV} \\
(\%)\end{array}$ \\
\hline $15 \beta-\mathrm{OH}-\mathrm{CPA}$ & $5.5 \pm 0.1$ & 0.9 & $0.72 \pm 0.01$ & 1.6 \\
$19-\mathrm{NT}$ & $7.6 \pm 0.1$ & 1.3 & 1 & - \\
CP & $12.9 \pm 0.1$ & 0.5 & $1.58 \pm 0.01$ & 0.9 \\
CPA & $18.1 \pm 0.3$ & 1.5 & $2.39 \pm 0.02$ & 0.9 \\
\hline \multicolumn{4}{c}{ Mean \pm SD $(\mathrm{n}=4)$}
\end{tabular}

Table 2. Recovery rates and peak height ratios to the internal standard (19-nortestosterone).

\begin{tabular}{c|c|c|c|c}
\hline \hline & $\begin{array}{c}\text { Recovery } \\
(\%)\end{array}$ & $\begin{array}{c}\text { CV } \\
(\%)\end{array}$ & $\begin{array}{c}\text { Peak } \\
\text { height } \\
\text { ratio }\end{array}$ & $\begin{array}{c}\text { CV } \\
(\%)\end{array}$ \\
\hline $15 \beta$-OH-CPA & $70.5 \pm 3.1$ & 4.4 & $57.7 \pm 1.2$ & 2.2 \\
19-NT & $74.6 \pm 4.0$ & 5.4 & 1 & - \\
CP & $79.6 \pm 4.7$ & 5.8 & $43.3 \pm 1.4$ & 3.3 \\
CPA & $81.4 \pm 2.9$ & 3.6 & $27.2 \pm 0.7$ & 2.7 \\
\hline \multicolumn{4}{c}{ Mean \pm SD (n=4) }
\end{tabular}


shows a chromatogram for a normal adult serum sample supplemented with $125 \mathrm{ng}$ each of CP, CPA and 15 $\beta-\mathrm{OH}-\mathrm{CPA}$, and $2.5 \mu \mathrm{g}$ of $19-\mathrm{NT}$, per $0.5 \mathrm{ml}$ of serum. The steroids showed good separation and the recovery rates were all sufficient. The coefficients of variation for the retention time and recovery rate were both satisfactorily low. The minimum detectable levels for CPA and $15 \beta-\mathrm{OH}-\mathrm{CPA}$ were considered to be 15 and $5 \mathrm{ng} / \mathrm{ml}$, respectively, when 0.5 $\mathrm{ml}$ of serum was used.

Fig. 2 shows a typical profile for a serum sample obtained from a patient with idiopathic true precocious puberty undergoing long-term CPA therapy $\left(62.5 \mathrm{mg} / \mathrm{m}^{2} /\right.$ day), for which peaks of CPA and $15 \beta-O H-$ CPA were detected and the concentrations of CPA and $15 \beta-\mathrm{OH}-\mathrm{CPA}$ were calculated to be 318 and $466 \mathrm{ng} / \mathrm{ml}$, respectively. Peaks of CP and other metabolites were not detected for any serum sample obtained from patients undergoing CPA therapy.

Intra-assay variances ranged from 0.9 to $6.2 \%$ for CPA and from 2.1 to $5.7 \%$ for $15 \beta-\mathrm{OH}-\mathrm{CPA}$, and the inter-assay variances

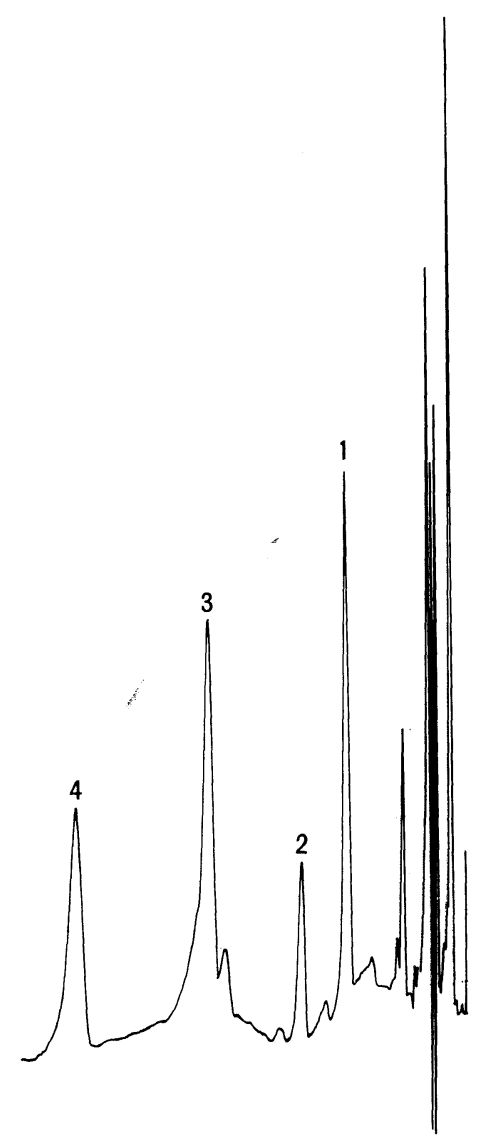

Fig. 1. Chromatogram of a normal adult serum sample supplemented with $125 \mathrm{ng}$ each of $\mathrm{CP}$, $\mathrm{CPA}$ and $15 \beta-\mathrm{OH}-\mathrm{CPA}$, and $2.5 \mu \mathrm{g}$ of $19-\mathrm{NT}$, per $0.5 \mathrm{ml}$ serum. 1: $15 \beta-\mathrm{OH}-\mathrm{CPA}, 2: 19$ NT, 3: CP, 4 : CPA.

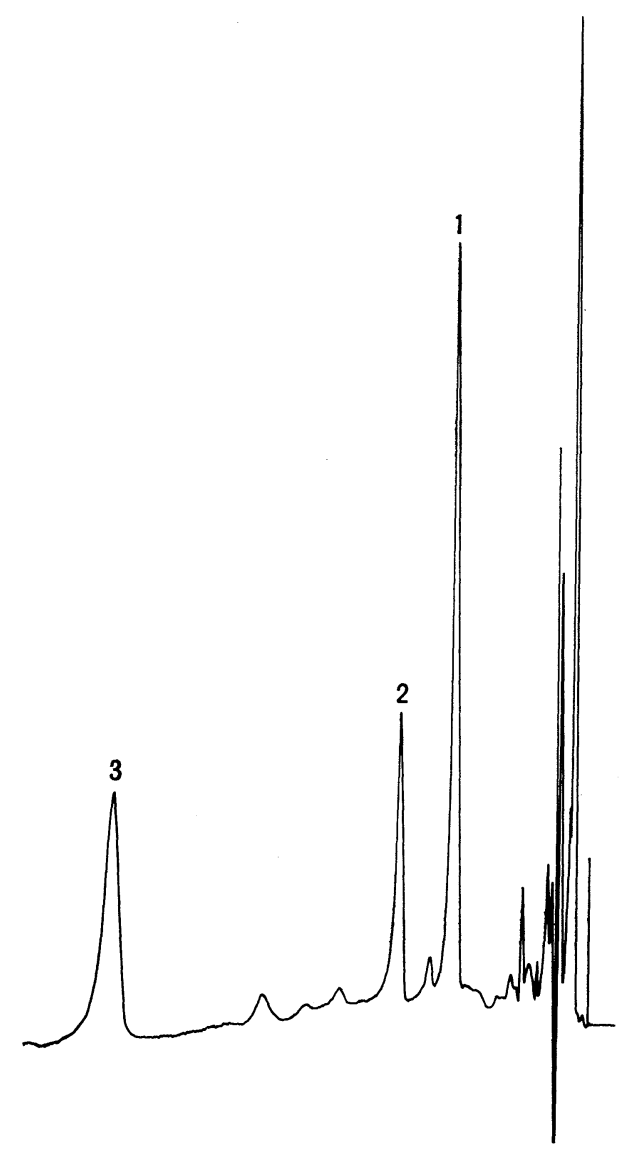

Fig. 2. A typical chromatogram for a patient with true precocious puberty undergoing longterm oral CPA administration. 1: $15 \beta-\mathrm{OH}-$ CPA (446 ng/ml), 2: 19-NT, 3: CPA (318 $\mathrm{ng} / \mathrm{ml})$. 
were 1.6 to $5.5 \%$ for CPA and 6.1 to $7.3 \%$ for $15 \beta-\mathrm{OH}-\mathrm{CPA}$. These values were all considered to be sufficiently low for the determination of the serum concentrations of the two steroids (Table 3).

Table 4 shows the serum concentrations of CPA and $15 \beta-\mathrm{OH}-\mathrm{CPA}$ in patients undergoing long-term oral CPA administration with various doses. The mean $15 \beta-\mathrm{OH}-\mathrm{CPA}$ concentrations were higher than those of CPA in all groups divided as to the doses administered. There were positive correlationship between the serum concentrations of these steroids and the CPA dosage (up to $150 \mathrm{mg} / \mathrm{m}^{2} /$ day) administered, but we did not observed a significant differences in these serum concentrations between the patients receiving high dose of CPA $\left(100-150 \mathrm{mg} / \mathrm{m}^{2} /\right.$ day), and those receiving very high doses of CPA (above $150 \mathrm{mg} / \mathrm{m}^{2} /$ day).

Table 3. Precision of the assay

Intra-assay variance

\begin{tabular}{r|r:r|r:r}
\hline & $\begin{array}{c}\mathrm{CPA} \\
(\mathrm{ng} / \mathrm{ml})\end{array}$ & $\begin{array}{c}\mathrm{CV} \\
(\%)\end{array}$ & $\begin{array}{c}15 \beta-\mathrm{OH}- \\
\mathrm{CPA}\end{array}$ & $\begin{array}{c}\mathrm{CV} \\
(\mathrm{ng} / \mathrm{ml})\end{array}$ \\
\hline Sample
\end{tabular}

Inter-assay variance

\begin{tabular}{r|c:c|c:c}
\hline \hline & $\begin{array}{c}\text { CPA } \\
(\mathrm{ng} / \mathrm{ml})\end{array}$ & $\begin{array}{c}\mathrm{CV} \\
(\%)\end{array}$ & $\begin{array}{c}15 \beta-\mathrm{OH}- \\
\mathrm{CPA} \\
(\mathrm{ng} / \mathrm{ml})\end{array}$ & $\begin{array}{c}\mathrm{CV} \\
(\%)\end{array}$ \\
\hline Sample E & $113 \pm 2$ & 1.6 & $278 \pm 17$ & 6.1 \\
F & $337 \pm 18$ & 5.5 & $478 \pm 35$ & 7.3 \\
\hline \multicolumn{4}{c}{ Mean \pm SD $(\mathrm{n}=3)$}
\end{tabular}

Table 4. Serum concentrations of CPA and $15 \beta-\mathrm{OH}-\mathrm{CPA}$ in patients undergoing oral CPA administration.

\begin{tabular}{|c|c|c|c|}
\hline $\begin{array}{c}\text { Dose } \\
\left(\mathrm{mg} / \mathrm{m}^{2} / \text { day }\right) \\
(\text { mean })\end{array}$ & $\mathrm{n}$ & $\begin{array}{c}\text { CPA } \\
(\mathrm{ng} / \mathrm{ml})\end{array}$ & $\begin{array}{c}15 \beta-\mathrm{OH}-\mathrm{CPA} \\
(\mathrm{ng} / \mathrm{ml})\end{array}$ \\
\hline$<50(30.5)$ & 4 & $92.0 \pm 42.7$ & $253 \pm 34.5$ \\
\hline $50 \sim 100(73.5)$ & 9 & $134 \pm 50.0$ & $384 \pm 158$ \\
\hline $100<150(127.9)$ & 14 & $400 \pm 195$ & $1176 \pm 495$ \\
\hline $150<(175.3)$ & 7 & $428 \pm 118$ & $1215 \pm 585$ \\
\hline
\end{tabular}

\section{Discussion}

CPA has been used as an antiandrogen in the treatment of adult women with acne vulgaris and/or hirsutism (Hammerstein et al., 1975; Moltz et al., 1982), and of adult men with advanced prostatic carcinoma (Jacobi, 1983) or hyper-sexuality (Laschet and Laschet, 1975), and the pharmacokinetics of CPA in humans have only been investigated in these adult subjects. Apart from these diseases, the most important use of CPA today is in the treatment of precocious puberty in children. However, not only the pharmacokinetics of CPA and its main and potential metabolite, $15 \beta-\mathrm{OH}-\mathrm{CPA}$, but also the relationship between the serum concentrations of these steroids and the clinical or endocrinological effects has not been sufficiently examined in children undergoing long-term oral CPA administration for the treatment of precocious puberty. Moreover, although it is well known that CPA has a suppressive effect on the adrenocortical function (Heinze et al., 1978), the relationship between the serum CPA and $15 \beta-\mathrm{OH}-\mathrm{CPA}$ levels and the extent of adrenocortical suppression is less well defined. We therefore attempted to resolve these points through more accurate determination of serum CPA and 15 $\beta-\mathrm{OH}-\mathrm{CPA}$ concentrations.

As to HPLC methods for the determination of CPA and its metabolites, Frith and Phillipou (1985) reported a reversedphase HPLC method which was applicable for the simultaneous determination of the CPA and $15 \beta-\mathrm{OH}-\mathrm{CPA}$ levels in plasma and urine. The equipment and the wavelength they used were basically the same as ours, but their extraction procedure was much more complex than ours. Instead of cyproterone propionate, which they originally synthesized and used as an internal standard, commercially available 19-NT was used for our method. Because the maximum 
absorbance of 19-NT was at around $246 \mathrm{~nm}$ and is different from the wavelength used $(284 \mathrm{~nm})$, it is necessary to use a large amount of 19-NT for the internal standard in this study. However, we have demonstrated that this large amount of 19-NT used does not have any undesirable effect on this analysis. With our modified HPLC method, the specific detection of the peaks of CPA and $15 \beta-\mathrm{OH}-\mathrm{CPA}$ in serum is considered to be much easier for the following reasons. (1) The appropriate wavelength for CPA and $15 \beta-\mathrm{OH}-\mathrm{CPA}$ determination was $284 \mathrm{~nm}$ with our method. Since many kinds of unconjugated intrinsic adrenal and gonadal steroids are not detectable at this wavelength (Cannell et al., 1981), and our extraction procedure involving diethyl ether excludes the sulfoconjugated intrinsic steroids which may exist in sera in great quantities, our method is considered to be specific for the determination of CPA and $15 \beta-\mathrm{OH}-\mathrm{CPA}$. As a matter of fact, no peaks other than those of CPA, $15 \beta-\mathrm{OH}-\mathrm{CPA}$ and 19-NT (internal standard) were seen in the chromatogram. With the RIA method, the peak concentration of serum CPA was reported to be $300 \pm 30($ mean $\pm \mathrm{SD}) \mathrm{ng} / \mathrm{ml}$ in normal adults after single oral administration of a $50 \mathrm{mg}$ tablet of CPA (Humpel et al., 1978). This value was approximately three times higher than that obtained with our method, ie., $76.1 \mathrm{ng} / \mathrm{ml}$. This difference is thought to be due to the cross-reactivities of other related steroids including $15 \beta$ $\mathrm{OH}-\mathrm{CPA}$, which inevitably interfere with the radioimmunoassay method. (2) The minimum detectable levels with this method were $15 \mathrm{ng} / \mathrm{ml}$ for CPA and $5 \mathrm{ng} / \mathrm{ml}$ for $15 \beta-\mathrm{OH}-\mathrm{CPA}$, respectively. These values are considered to be sufficiently low for determination of the serum concentrations of these steroids in patients undergoing routine oral CPA administration. (3) The precision of this method was satisfactory, and the recovery rate on extraction was also sufficient and constant.
Although the serum concentration of $\mathrm{CP}$ can be simultaneously measured with our method, if it is present in serum, it was, as reported previously (Frith and Phillipou, 1985), not detected in any serum samples from the patients receiving CPA. In humans, CP is known to be present in urine and bile juice chiefly as a glucuronide conjugate (Kopp et al., 1976), however, we ourselves have not yet studied the CP contents in such specimens. They also reported that highly polar unconjugated steroid was detected in human serum by a thin layer chromatographic procedure after ${ }^{14} \mathrm{C}$-labelled CPA administration, but we could not find any peak representing this metabolite by our method.

In conclusion, using our new reversedphase HPLC method, we could measure CPA and 15 $\beta-\mathrm{OH}-\mathrm{CPA}$ in serum easily and simultaneously without any interference due to other intrinsic adrenal or gonadal steroids. By means of this method it will be possible to study not only the pharmacokinetics of CPA and 15 $\beta-\mathrm{OH}-\mathrm{CPA}$ but also the relationship between CPA dosage and the effects on adrenal and gonadal steroid production in children suffering from precocious puberty who are undergoing longterm CPA therapy.

\section{Acknowledgements}

The authors wish to acknowledge the donation of cyproterone acetate, cyproterone and $15 \beta$-hydroxycyproterone acetate by Schering AG.

\section{References}

Cannell, G. R., R. H. Mortimer and M. J. Thomas (1981). High-performance liquid chromatographic estimation of cyproterone acetate in human plasma. J. Chromatogr. 226, 492497.

Frith, R. G. and G. Phillipou (1985). 15-Hydroxycyproterone acetate and cyproterone ace- 
tate levels in plasma and urine. J. Chromatogr. $338,179-186$.

Hammerstein, J., J. Meckies, I. Leo-Rossberg, L. Moltz and F. Zielske (1975). Use of cyproterone acetate (CPA) in the treatment of acne, hirsutism and virilism. J. Steroid Biochem. 6, 827-836.

Heinze, F., W. M. Teller, H. L. Fehm and A. Joos (1978). The effect of cyproterone acetate on adrenal cortical function in children with precocious puberty. Eur. J. Pediatr. 128, $81-88$.

Hümpel, M., G. Dogs, H. Wendt and U. Speck (1978). Plasmaspiegel und Pharmakokinetik von Cyproteroneacetat nach oraler Applikation als 50-mg-Tablette bei 5 Männern. Arzneim.-Forsch./Drug Res. 28 (1), 319-322.

Jacobi, G. H. (1983). Intramuscular cyproterone acetate treatment for advanced prostatic carcinoma: result of the first multicentric randomized trial. In: Androgens and Anti- androgens (F. H. Schroder, ed.), Schering Nederland B. V. pp. 133-146.

Kopp, R., U. Speck and W. Mutzel (1976). Schering AG Report No. 2391.

Laschet, U. and L. Laschet (1975). Antianrdogens in the treatment of sexual deviations of men. J. Steroid Biochem. 6, 821-826.

Moltz, L., U. Schwartz and J. Hammerstein (1982). Management of cutaneous virilism with cyproterone acetate. In: Androgens and Anti-androgens Therapy (S. L. Jeffcoate, ed.), John Wiley, Chichester. pp. 113-143.

Nieuweboer, B. and K. Lübke (1977). Radioimmunological determination of cyproterone acetate. Hormone Res. 8, 210-218.

Schleusener, A., Y. Nishino, M. Albring, F. Neumann and S. Beier (1980). Endocrine profile of a cyproterone acetate (CPA) metabolite and its potential clinical use. Acta Endocrinol. 234, 106 (Abstract). 